\title{
Perancangan Dan Usability Evaluation Prototipe Informasi Akademik Menggunakan Metode Rapid Application Development
}

\author{
Darmin Karim $^{1}$, Harry Budi Santoso ${ }^{2}$ \\ Program Studi S2 Teknik Informatika ${ }^{1}$, Universitas AMIKOM Yogyakarta \\ Fakultas Ilmu Komputer ${ }^{2}$, Universitas Indonesia \\ darminkarim2@gmail.com
}

\begin{abstract}
Abstrak
Tujuan dari penelitian ini adalah mengembangkan dan mengevaluasi sebuah Sistem Informasi Akademik Berbasis Rapid Application Development (RAD) yang mempunyai database akademik yang real, sehingga memudahkan bagian akademik dalam mengelola nilai sesuai sistem yang ada serta dapat menghasilkan informasi yang akurat dan bermutu untuk menunjang proses penyelenggaraan pendidikan. Sistem Informasi Akademik dalam studi ini dikembangkan dengan metode $R A D$, yaitu metode pengembangan sistem informasi yang membutuhkan waktu yang relatif singkat. Dalam pengembangan sistem informasi yang normal biasanya memerlukan waktu minimal 60 hari, namun dengan menggunakan metode $R A D$, sistem dapat diselesaikan dalam waktu 30-60 hari. Tujuan utama menggunakan metode $R A D$ adalah memberikan suatu sistem yang dapat memenuhi harapan dan kebutuhan dari user. Perancangan Dan Usability Evaluation Prototipe Sistem Informasi Akademik Menggunakan Metode $R A D$ akan menggunakan konsep sistem database server yang mempunyai arsitektur Multitier yang terdiri dari Interface, Database Server dan Logic Server, sehingga sangat membantu dalam pengembangan sistem selanjutnya apabila terjadi perubahan regulasi atau aturan pada Akademi Ilmu Komputer (AIKOM) Ternate.

Kata Kunci: Sistem Informasi Akademik, Menggunakan RAD
\end{abstract}

\begin{abstract}
The objectives of this study are to develop and evaluate an Academic Information System Based on RAD that has a real academic database, thus facilitating the academic part in managing values according to the existing system and can produce accurate and quality information to support the process of implementing education. Academic Information System Using Rad (Rapid Application Development) developed with the RAD (Rapid Application Development) method, RAD is a method of developing information systems that require a relatively short time. In the development of a normal information system, it usually requires a minimum of 60 days, but by using the RAD method, the system can be completed within 3060 days. The main purpose of using the RAD method is to provide a system that can meet the expectations and needs of the user. Design and Usability Evaluation of the Academic Information System Prototype Using the RAD Method will use a database server system concept that has a Multitier architecture consisting of Interface, Database Server and Logic Server, so it is very helpful in developing the next system if there is a change in regulation or rules at the Computer Science Academy (AIKOM) Ternate.
\end{abstract}

Keywords: Academic Information System, Using RAD

\section{PENDAHULUAN}

Perkembangan teknologi saat ini, peran komputer banyak dirasakan dalam membantu kerja manusia apalagi dengan diciptakannya sebuah sistem terstruktur yang dapat berinteraksi dengan berbagai pengguna (User). Informasi yang cepat dan mudah sudah menjadi kebutuhan mutlak untuk membangun sebuah sistem terstruktur yang lebih efektif dan efisien. 
Jika pencarian informasi yang dibutuhkan, seperti daftar mahasiswa yang terkena 'masalah akademik', rekap laporan kehadiran, profil prestasi mahasiswa suatu angkatan, dan sebagainya, dilakukan dengan cara klasik atau manual seperti melalui kertas daftar nilai, daftar kehadiran, dan sebagainya, maka cara ini tidak akan cukup efisien. Apalagi ditambah jika jumlah mahasiswanya sudah semakin banyak dari ratusan bahkan ribuan mahasiswa. Kegiatan pengelolaan akademik, seperti pengelolaan Database mahasiswa, dosen dan karyawan pengelolaan mata kuliah, nilai akademik, nilai kelakuan, manajemen peringatan, profil (Trend), atau masalah pelaporan, seperti laporan statistik, rekapitulasi, dan sebagainya merupakan kegiatan yang faktor rutinitasnya cukup besar, sehingga rentan terjadi kesalahan, mudah terjadi inefisiensi, dan kontra produktif jika tidak menggunakan alat bantu

Sistem dokumentasi, pelaporan dan pengolahan serta penyajian data dan informasi yang baik menunjukkan kualitas manajemen akademik yang baik. Informasi yang bersumber dari data mentah (Raw Data) merupakan dasar yang bermutu bagi pembangunan sistem dokumentasi dan pelaporan. Hal ini perlu didukung pula oleh ketentuan, aturan dan ketetapan yang baku dari tingkat manajemen yang membutuhkan (Upper Level Management) [1]. Pekerjaan membuat laporan dan dokumentasi sering kali diabaikan. Proses pembuatan laporan sering secara mendadak dan bukan diambil dari data mentah, tetapi dari data agregat sehingga memiliki tingkat akurasi yang tinggi. Penggunaan Hardcopy atau kertas membutuhkan ruang yang cukup besar.

Di sisi lain, dengan digitalisasi, akan sangat memungkinkan tersimpannya dokumentasi secara digital yang aman dan tidak membutuhkan ruang besar, namun dapat diakses lebih cepat. Dengan itu diperlukan teknik pendekatan yang tepat dalam membangun dan mengevaluasi sistem informasi akademik. Pendekatan tersebut harus melibatkan beberapa aspek penilaian untuk mengevaluasi data akademik serta mampu memanfaatkan data informasi akademik yang tersimpan dalam Database. Pentingnya menggunakan Usability Evaluation, karena dalam pengembangan sistem interaktif, salah satu bagian dari proses untuk memahami kebutuhan pengguna yaitu mencangkup Learnability, Efficiency, Memorabiliy, Errors, (LEMERS) dalam pengujian kebergunaan [2].

Oleh karena itu, berdasarkan latar belakang tersebut peneliti merancang sebuah Sistem Informasi Akademik pada kampus AIKOM untuk memenuhi kebutuhan sebuah perguruan tinggi dimana peneliti berada, yaitu di kampus AIKOM Ternate. Sistem yang dibangun dengan menerapkan metode RAD karena pertimbangan aspek waktu dan biyaya yang lebih sesuai untuk pengembangan aplikasi yang termasuk dalam kategori besar. Karena RAD memiliki keunggulan dalam hal kecepatan, ketepatan, dan biaya yang lebih rendah, serta melibatkan pengguna dalam pengembangannya sehingga dapat meningkatkan kepuasan dalam penggunaan sistemnya

\section{Rumusan Masalah}

1. Belum tersajinya sistem informasi akademik secara sistematis berbasis IT (Information Technologies) yang diperlukan bagi pengambilan keputusan terhadap aspek perencanaan, pemerkasaan, 
pengorganisasian dan pengawasan akademik.

2. Perlunya perbaikan sistem dan prosedur kerja terutama untuk kemudahan akses informasi dan efisiensi waktu pengerjaan.

3. Belum adanya sistem informasi akademik yang lebih profesional

\section{Batasan Penilitian}

Mengingat luasnya cakupan dalam pemanfaatan teknologi informasi dalam sistem informasi akademik, maka dalam penelitian ini penulis membatasi pembahasaanya pada proses pengisian KRS, penjadwalan kuliah, pembuatan KHS, dengan implementasi dalam prototipe.

\section{Tujuan Penelitian}

1. Membangun suatu sistem informasi akademik berbasis teknologi web memgunakan metode RAD yaitu suatu sistem informasi yang didukung teknologi yang handal dan dibangun dengan fasilitas untuk mengelola data akademik, memberikan beberapa informasi tentang data akademik dan membuat laporan akademik.

2. Usability Testing pada penelitian ini untuk mengetahui seberapa besar nilai penerimaan Usability oleh User terhadap perangkat lunak aplikasi yang telah dibuat.

3. Diharapkan dari hasil penelitian ini dapat memberikan sumbangan pemikiran dalam upaya meningkatkan kualitas pelayanan dibidang administrasi akademik dan mengembangkan sistem informasi akademik sebagai solusi bagi manajemen sistem informasi akademi di Aikom Ternate.

\section{Manfaat Penelitian}

1. Membangun perguruan tinggi dalam pengelolahaan data akademik dengan membangun sistim informasi akademik yang berbasis komputer secara sistematis, terarah dan lengkap dan lebih mengefisiensikan pekerjaan dalam instansi tersebut.

2. Membantu dan memudahkan mahasiswa di perguruan tinggi tersebut untuk mengaksen informasi akademik yang dibutuhkan-nya di mana saja (Anywhere) dan kapan saja (Anytime).

3. Efisiensi media dan ruang yang digunakan untuk penyimpanan data atau arsip perguruan tinggi (Paperlest) untuk pencatatan data-data perguruan tinggi (Akademik) pengurangan ruang untuk penyimpanan kertas-kertas tersebut, pengurang tenaga perawat kertas dan ruang tersebut.

4. Meningkatkan kemampuan mengelolah data akademik, mengelolah yang di maksut meliputi kelengkapan data, kerincian data, keamanan data, kerahasian data, caracara pemasukan dan pengambilan data, dan sebagainya

\section{Tinjauan Pustaka}

Menurut Nur Rochmah Dyah P.A, Efawan Retza Arsandy Program Studi Teknik Inofrmatika Universitas Ahmad Dahlan Yogyakarta [6], membangun sebuah aplikasi sistem informasi geografis untuk sebaran sekolah berdasarkan permasalahan dalam bidang pendidikan yang pada saat ini diperlukan suatu kebijakan dari pemerintah dalam hal ini Departemen Pendidikan Nasional yang komprehensif dan bersifat multidimensi, untuk informasi sebaran sekolah yang bisa dijadikan data awal guna menentukan kebijakan lebih lanjut atau sebagai spasial 
sistem pengambilan keputusan (Spatial Decision Support System). Sistem informasi geografis (SIG) yang dikembangkan-nya telah mampu mengakomodasi data spasial dengan data atribut menjadi sebuah tampilan yang mampu menyajikan analisis keruangan

Menurut penelitian terkait "Rancng bangun system Rekomendasi Obyek Wisata Menggunakan Metode Algoritma Vfi5, penelitian system rekomendasi pariwisata dengan pengujian usabilitas diuji dengan menerapkan metode kuisioner usabilitas dengan tipe kuisioner (LERMErS) [7]. Hasil rekap nilai usabilitas tersebut menunjukan nilai-nilai kepuasan atas penerimaan pengguna (user acceptance) terhadap masing-masing atribut. Hasil tersebut di evaluasi dengan menyesuaikan hubungan dengan masingmasing aspek usability yang dijelaskan pada sub bab ini, dapat di katakana perangkat lunak aplikasi web SiPjogja.com yang telah memiliki nilai Usability yaitu Learnability, Efficiency, Memorability, Errors, dan Satisfaction yang baik [7] menghasilkan sebuah sistem dengan kualitas yang tinggi, pengembangan dan biaya yang lebih rendah dari pada siklus pengembangan yang telah ada. Penelitian ini akan dikembangkan sistem informasi untuk mengelola data "sumber daya sekolah" yang dapat diakses dengan pemnafaatan tekonologi internet. Sistem dikembangkan dengan model proses Rapid Application Development (RAD). Metode tersebut digunakan dengan alasan untuk mempersingkat waktu pengembangan. Selain itu sistem yang dikembangkan memanfaatkan Google Map API untuk pemetaan lokasi sekolah

Menurut [9] Gandhi Narrottama, yang berjudul "Perancangan dan Implementasi Sistem Informasi Tugas Akhir Fakultas
Teknologi Informasi UKSW Berbasis Web dengan Menggunakan Rapid Application Development (RAD)", dijelaskan bahwa sistem yang dikembangkan bertujuan untuk mempercepat proses administrasi, memudahkan dokumentasi proses kegiatan penelitian mahasiswa dari awal sampai selesai dan menjadikan proses administrasi pengumpulan tugas akhir lewat satu pintu. Rapid Aplication Development (RAD) merupakan solusi untuk memperoleh sebuah sistem yang dapat menjawab kebutuhan akan sistem pendaftaran tugas akhir yang dapat mengintegrasikan semua pihak yang berkepentingan dalam jangka pendek yang harus dipenuhi guna meningkatkan kualitas pelayanan

Menurut [10], Unika Kartika Dewi, Yusi Tjroni Mursityo, Rekyan Regasari Mardi Putri dengan judul "Analisis Usabelity Aplikasi Mobile Pemesanan Layanan Taksi Perdana Menggunakan Metode Webuse Dan Heuristic Evaluation". Penelitian ini bertujaan untuk mengatahui level Usability kedua antar muka, aplikasi apakah sudah memiliki level yang baik, menggali masalah Usability yang ada, mendapat evaluasi masalah Usability oleh ahlinya, mengevaluasi Usability aplikasi perdana Taksi secara komprehensif dan menghasilkan rekomendasi perbaikan masalah Usability yang ditemukan pada aplikasi untuk meningkatkan level Usability menjadi lebih baik

\section{LANDASAN TEORI \\ Sistem}

Secara mendasar, sistem merupakan kumpulan dari seperangkat komponen yang saling berkaitan, memiliki batas yang jelas, dan bekerja sama untuk mencapai tujuan tertentu [3]. Sistem memiliki tiga fungsi dasar, yaitu: 
a. Input menangkap elemen yang akan diproses dalam sistem.

b. Pengolahan melibatkan proses mentransfer unsur-unsur yang telah mengkomversikan Input menjadi Output

c. Output berperan dalam mentransver unsur-unsur yang telah di hasilkan sesuai dengan tujuan yang diharapkan.

\section{Defenisi Informasi}

Menurut Laudon [4], informasi adalah data yang telah dibentuk menjadi bentuk yang berarti dan berguna bagi manusia. Sementara data adalah aliran fakta-fakta mentah yang mempresentasikan peristiwaperistiwa yang terjadi dalam organisasi atau lingkungan fisik sebelum di atur dan disusun menjadi bentuk yang dapat di pahami dan digunakan manusia. Sementara Turban et.al [13] mendefenisikan informasi sebagai data yang telah terorganisir sehingga mereka memiliki makna dan nilai bagi para penerima

\section{Rapid Application Development}

RAD (Rapid Application

Development) merupakan metode gabungan dari beberapa pendekatan terstruktur. Metode $R A D$ menggunakan metode iteratif (berulang) dalam mengembangkan sistem dimana model bekerja sistem dikonstruksikan di awal tahap pengembangan dengan tujuan menetapkan kebutuhan pengguna. Metode $R A D$ menekankan cakupan pemodelan bisnis (bussiness modelling), pemodelan data (data modelling), pemodelan proses (process modelling), pembuatan aplikasi (apzxplication generation) dan pengujian (testing). Metode ini dapat dikerjakan dalam waktu yang singkat hanya membutuhkan waktu 30-90 hari untuk menyelesaikan sistem perangkat lunak tersebut [14]

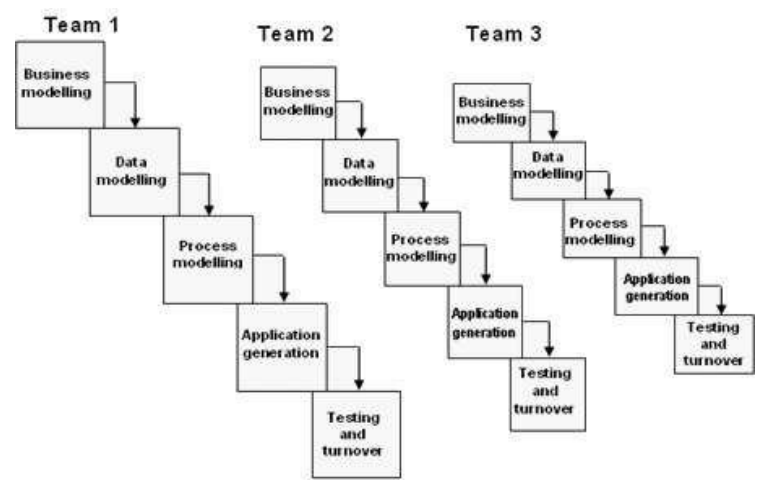

Gambar 1. Model RAD

Sumber: M. Safi [8]

Berikut Fase Pemodelan pada RAD [8]

a. Fase pemodelan bisnis (Bussiness Modeling) merupakan aliran informasi yang berada diantara fungsi- fungsi bisnis dan di modelkan dengan cara menampilkan beberapa pertanyaanpertanyaan berikut:Informasi apa yang mengendalikan proses bisnis, kemana informasi itu pergi, siapa yang memprosesnya.

b. Fase pemodelan data (Data Modeling) merupakan aliran informasi yang didefinisikan sebagai bagian dari fase pemodelan bisnis yang disaring ke dalam serangkaian objek data yang dibutuhkan untuk menopang bisnis tersebut. Karakteristik atau atribut dari setiap objek diidentifikasi dan hubungan antara objek-objek tersebut didefinisikan.

c. Fase pemodelan proses (Process Modeling) merupakan aliran informasi yang di definisikan dalam fase pemodelan di mana data ditransformasikan untuk mencapai aliran informasi yang perlu bagi implementasi sebuah fungsi bisnis. Gambaran pemrosesan diciptakan untuk menambah, memodifikasi, 
menghapus atau mendapatkan kembali sebuah objek data.

d. Fase pengembangan aplikasi (Application Generation) merupakan proses menciptakan perangkat lunak dengan menggunakan bahasa pemrograman generasiketiga yang konvensional, RAD lebih banyak memproses kerja untuk memakai lagi komponen program yang telah ada atau menciptakan komponen yang bisa dipakai lagi. Pada semua kasus, alatalat bantu otomatis dipakai untuk memfasilitasi kontruksi perangkat lunak.

e. Fase pengujian dan pergantian (Testing and Turnover) adalah proses dari RAD yang menekankan pada pemakaian kembali komponen yang telah diuji. Hal ini dimaksudkan mengurangi keseluruhan waktu pengujian. tapi komponen baru harus diuji

\section{METODE PENELITIAN}

\section{Metode Pengumpulan Data}

1. Studi Pustaka

Studi pustaka merupakan kegiatan yang berkaitan dengan pengkajian terhadap sumber-sumber referensi untuk memperoleh landasan teori, konseptual dan praktis tentang permasalahan penelitian. Studi pustaka ini dilakukan dengan mendapatkan data dari literatur berupa buku, jurnal.

2. Studi Lapangan

Kegiatan studi lapangan dalam penelitian ini dilakukan melalui pengumpulan data yang berkaitan dengan permasalahan sistem informasi yang ada dilapangan. Studi lapangan ini meliputi observasi dan wawancara.

3. Pembuatan Sistem

Tahap ini merupakan tahapan dalam merancang sistem informasi akademik yang sesuai dengan analisa kebutuhan pengguna dan kebutuhan sistem. Dengan menggunakan bahasa pemograman Framework Codeigniter PHP. Metode pengembangan sistem yang digunakan dalam penelitian ini berdasarkan konsep Software Engineering dengan proses pengembangan Software metode Rapid Application Development (RAD).

\section{Metode Usability Testing}

Metode Usability Testing yang digunakan dalam penelitian ini adalah metode kuesioner dengan respon pengguna dari berbagai usia. Responden yang dipilih dari berbagai usia dengan pertimbangan telah mengerti mengenai web, tetapi belum pernah mengakses web yang diuji sebelumnya. Mengingat waktu dan biyaya yang diberikan untuk meminimalkan pengujian pada penelitian ini.

Secara teknis, Usability Testing, proses ini dilakukan dengan menyebarkan Task (atau skenario) dan kuesioner secara Online menggunakan layanan Google Forms sebagai kuesionernya beserta aplikasi (sistem). Kemudian penguji yang bersedia melakukan pengujian, diminta menggunakan sistem dengan mengikuti beberapa Task (skenario). Task atau tugas yang diberikan meliputi seluruh kegiatan interaksi antara pengguna/penguji terhadap sistem

Pada Task tersebut mengharuskan pengguna / penguji untuk mencoba keseluruhan dari fitur- fitur yang terdapat pada aplikasi (sistem) dengan melakukan inputan atau interaksi yang berbeda-beda sesuai task yang diberikan. Dimana TaskTask tersebut adalah seperti pada Tabel 1.

Tabel 1. Task atau tugas usability testing 


\begin{tabular}{|l|l|}
\hline No & Task/Tugas \\
\hline 1 & $\begin{array}{l}\text { Melakukan browsing sebagai user dalam web } \\
\text { aplikasi (SiAkom.com.) }\end{array}$ \\
\hline 2 & Cari dalam web aplikasi ini, halaman beranda \\
\hline 3 & $\begin{array}{l}\text { Masukan inputan data berupa data akademik } \\
\text { hasil } \\
\text { inputan yang sesuai perintah yang ada } \\
\text { didalam menu halaman beranda }\end{array}$ \\
\hline
\end{tabular}

\section{Kuesioner}

Kuesioner merupakan teknik pengumpulan data yang di lakukan dengan cara memberi seperangkat pertanyaan tertulis kepada responden untuk dijawabnya. Dalam penelitian ini, kuesioner digunakan untuk mengukur tingkat kepuasan pengguna. Kuesioner yang digunakan mengacu pada System Usability Scale (SUS). SUS merupakan sebuah standar kuesioner yang mengukur kepuasan pengguna dalam menggunakan sebuah sistem [11].

Adapun butir-butir dari ke-10 pertanyaan SUS yang telah diterjemahkan ke dalam Bahasa Indonesia dan yang telah divalidasi dapat disajikan melalui Tabel 2 berikut ini, yaitu: Tabel 2. Butir-butir Kuesioner System Usability Scale (SUS) [12]

Tabel 2. Butir-butir kuesioner

\begin{tabular}{|l|l|}
\hline No & \multicolumn{1}{|c|}{ Butir Pertanyaan } \\
\hline 1 & Saya berpikir menggunakan sistem ini lagi \\
\hline 2 & $\begin{array}{l}\text { Saya merasah sistem ini rumit untuk } \\
\text { digunakan }\end{array}$ \\
\hline 3 & $\begin{array}{l}\text { Saya merasah sistem ini mudah untuk } \\
\text { digunakan }\end{array}$ \\
\hline 4 & $\begin{array}{l}\text { Saya membutuhkan bantuan dari orang lain } \\
\text { atau } \\
\text { teknik dalam menggunakan sistem ini }\end{array}$ \\
\hline 5 & $\begin{array}{l}\text { Saya merasah fitur-fitur sistem ini berjalan } \\
\text { dengan semestinya }\end{array}$ \\
\hline 6 & $\begin{array}{l}\text { Saya merasah ada banyak hal yang tidak } \\
\text { konsisten (tidak serasi) pada sistem ini }\end{array}$ \\
\hline 7 & Saya merasah orang lain akan memahami cara \\
\hline & menggunakan sistem ini dengan cepat \\
\hline 8 & Saya merasah sistem ini membingungkan \\
\hline
\end{tabular}

\begin{tabular}{|l|l|}
\hline 9 & $\begin{array}{l}\text { Saya merasah tidak } \\
\text { Ada hambatan } \\
\text { menggunakan sistem } \\
\text { ini }\end{array}$ \\
\hline 10 & $\begin{array}{l}\text { Saya perlu membiasakan diri terlebih dahulu } \\
\text { sebelum menggunakan sistem ini }\end{array}$ \\
\hline
\end{tabular}

Versinya SUS juga telah divalidasi dengan 10 responden seperti yang disebutkan sebelumnya dibagian sebelumnya. Ini instrumen memiliki kesetaraan semantik sebelum yang sama artinya dengan SUS asli dan tidak ada gramatikal kesulitan dalam versi terjemahan. Selain itu, Cronbachs Hasil Alpha dengan melibatkan 108 siswa menunjukkan bahwa Versi Bahasa Indonesia SUS dianggap dapat diandalkan sebelum skor yang berada di atas 0,7 (Lihat Tabel 2). Hasilnya juga menunjukkan bahwa instrumen ini masih dapat diandalkan jika salah satu item tersebut dihapus karena skor Cronbachs tidak diubah secara signifikan dan tetap konsisten

Tabel 3. Hasil Alpha Versi Cronbachs dari SUS Versi Indonesia Statistik Keandalan

\begin{tabular}{|l|l|}
\hline Cronbach's Alpha & N of Items \\
\hline 0,841 & 10 \\
\hline
\end{tabular}

\section{ANALISIS DAN PERANCANGAN Analisis Kebutuhan Pengguna}

Tahapan ini dilakukan untuk mengidentifikasi kebutuhan sistem untuk melakukan analisa sebagai landasan dan kerangka berpikir dari perancangan sistem yang akan dilakukan. Sistem yang akan dibangun yaitu sebuah perangkat lunak atau aplikasi sistem informasi akademik yang diberi nama SiAkom sesuai dengan alamat untuk mengakses aplikasi tersebut via web yaitu SiAkom.com. SiAkom adalah singkatan dari "Sistem Informasi 
Akademik AikomTernate". Selanjutnya dibuat suatu arsitektur sistem dapat dilihat pada Gambar 2

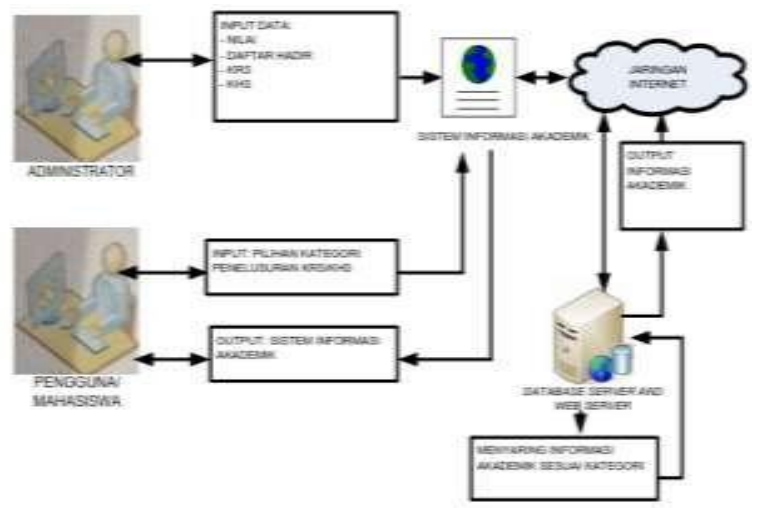

Gambar 2. Arsitektur Sistem Informasi Akademik Aikom

Arsitektur sistem informasi akademik (SiAkom) dalam penelitian ini diperlihatkan pada Gambar 2. Dalam arsitektur sistem terdiri dari dua bagian utama yaitu, Client Side dan Server Side. Client Side merupakan bagian sistem yang berhubungan dengan pengguna sistem informasi akademik yaitu mahasiswa yang mencari informasi mengenai data akademik. Pada Clien Side sistem berjalan melalui Web Browser yang melalukan Request ke Web Server sesuai dengan masukan pengguna yaitu berupa Keyword pencarian atau pilihan kategori pencarian. Pada Server Side, Web Server akan merating kumpulan data objek wisata yang tersimpan dalam Database sesuai dengan masukan pengguna. Web Server akan memberikan Reply keluaran berupa informasi akademik terhadap Request yang dikirimkan oleh pengguna sistem informasi akademik melalui Web Browser.

\section{Analisis Data Kuantitatif}

Analisis terhadap data kuantitatif dalam penelitian ini diperoleh melalui Task Scenarios dan pengisian kuesioner SUS. Selanjutnya hasil yang terdapat pada
Task Scenarios tersebut, kemudian diolah dan digunakan untuk menganalisis tinggkat evektifitas dan efisiensi aplikasi sedangkan hasil pengisian kuesioner SUS digunakan untuk menganalisis tingkat kepuasan pengguna.

\section{Analisis Efektifitas}

Analisis terhadap tingkat efektifitas, dapat diukur berdasarkan tingkat keberhasilan User dalam menyelesaikan tugas. Adapun parameter Usability yang dapat digunakan untuk mengukur tingkat kesuksesan User menyelesaikan tugas, yaitu:

Success Rate $=\{($ Success $+($ Partial Success $x$

$0,5)\} /$ Task $\} \times 100 \%$

Selanjutnya, hasil pengukuran tingkat kesuksesan tersebut diinterprestasikan dengan berpatokan pada standar acuan litbang Depdagri pada tahun 1991 guna mengetahui tingkat efektifitas seperti yang terlihat pada tabel 4 berikut,

Tabel 4. Standar Kuesioner System Usability Scale

\begin{tabular}{|l|l|l|}
\hline No & Rasio Efektifitas & Tingkat Pencapaian \\
\hline 1 & $40 \%$ & Sangat Tidak Efektif \\
\hline 2 & $40 \%-59 \%$ & Tidak Efektif \\
\hline 3 & $60 \%-79,99 \%$ & Cukup Efektif \\
\hline 4 & $\geq 80 \%$ & Sangat Efektif \\
\hline
\end{tabular}

\section{Analisis Efisiensi}

Analisis terhadap tingkat efisiensi, diukur berdasarkan lamanya waktu yang dibutuhkan User untuk menyelesaikn tugas yang diberikan, adapun indikator penilaian terhadap lamanya waktu penyelesaian tugas dapat disajikan melalui Tabel 5 berikut, yaitu

Tabel 5. Interval Waktu

\begin{tabular}{|l|l|l|}
\hline No & Lamanya Waktu & Kualifikasi \\
\hline 1 & 1 menit -5 menit & Sangat cepat \\
\hline
\end{tabular}




\begin{tabular}{|l|l|l|}
\hline 2 & 6 menit -10 menit & cepat \\
\hline 3 & 11 menit -15 menit & lambat \\
\hline
\end{tabular}

\section{Analisis Kepuasan Pengguna}

Analisis terhadap tingkat kepuasan pengguna dalam Usability Testing, diukur dan di analisis menggunakan kuesioner SUS yang di sebarkan kepada User setelah User menyelesaikan tugas. Kuesioner SUS terdiri dari 10 pertanyaan di mana setiap pertanyaan menggunakan skala Likert sebanyak lima sampai tujuh buah skala. Skala Likert digunakan untuk mengukur sikap, pendapat, dan perspektif seseorang atau sekelompok orang tentang fenomena sosial. Penggunaan Skala Likert dalam penelitian ini menggunakan lima buah skala dengan ketentuan sebagai berikut, yaitu 1 = Sangat tidak setuju (STS), 2 = Tidak Setuju (TS), 3 = Ragu-Ragu (RR), 4 $=$ Setuju (S), dan $5=$ Sangat Setujuh (SS) yang kemudian dilambangkan dengan gambar Smileymeter guna membantu User mengekspresikan kepuasan mereka terhadap aplikasi tersebut.

\section{Analisis Data Kualitatif}

Analisis data kualitatif dalam penelitian ini dapat di peroleh melalui kegiatan Usability Testing yaitu mengidentifikasi target pengujian yang kemudian di lanjutkan dengan menyebarkan Task Scenarios untuk di kerjakan dan di selesaikan oleh responden. Hasil dari data-data tersebut kemudian di analisis secara manual dengan mengidentifikasikan masalah - masalah yang ditemukan. Kemudian berdasarkan permasalahan yang ditemukan tersebut, selanjutnya di rangkum dan di buat rekomendasi perbaikan dan menghasilkan Prototype guna pengembangan selanjutnya.

\section{Perancangan Sistem}

Tahap perancangan sistem merupakan tahapan dalam merancang sistem informasi akademik ke dalam sistem aplikasi SiAkom, yang sesuai dengan analisa kebutuhan pengguna dan kebutuhan sistem. Dengan menggunakan bahasa pemrograman Framework Codeigniter PHP. Metode pengembangan sistem yang digunakan dalam penelitian ini berdasarkan konsep Software Engineering dengan proses pengembangan Software metode Rapid Application Development (RAD). Proses RAD merupakan pengembangan perangkat lunak sekuensial linear yang menekankan siklus perkembangan yang pendek.

\section{IMPLEMENTASI DAN PEMBAHASAN}

\section{Halaman Login}

Halaman login merupakan halaman awal sistem, halaman login digunakan untuk admin yang akan masuk kedalam sistem. Untuk masuk ke dalam sistem dibutuhkan Username dan Password. Implementasi halaman login sistem admin ditunjukan pada Gambar 3

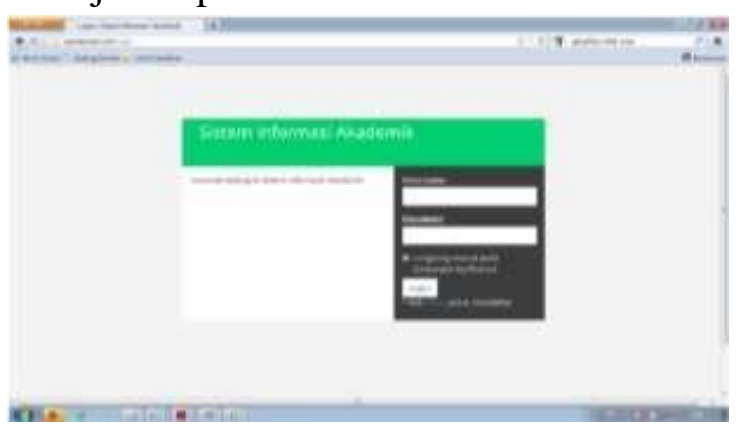

Gambar 3. Halaman Login

\section{Halaman Data Admin}

Halaman data admin merupakan daftar admin dari sistem ini kita dapat menambah User admin dengan menu input data berupa input data mahasiswa, dosen, mata kulia, pengampu, semester, nilai peringatan, dengan klik tambah data untuk 
membuat User baru, seperti terlihat pada Gambar 4

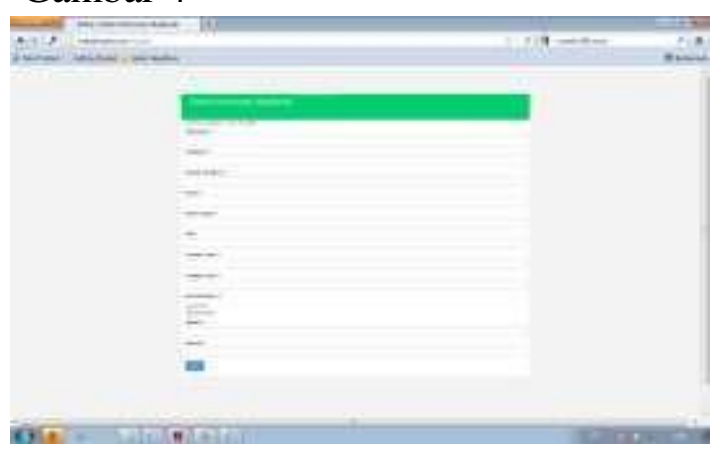

Gambar 4. Halaman Data Admin

\section{Halaman Data Mahasiswa}

Halaman data mahasiswa adalah suatu data yang berisi Username, Password, nama mahasiswa, tempat lahir, tanggal lahir, jenis kelamin, agama, alamat dan sebagainya. Admin bisa menambahkan data mahasiswa baru dengan cara mengisikan isian seperti pada gambar kemudian klik tambah data. Yang ditunjukan pada Gambar 5

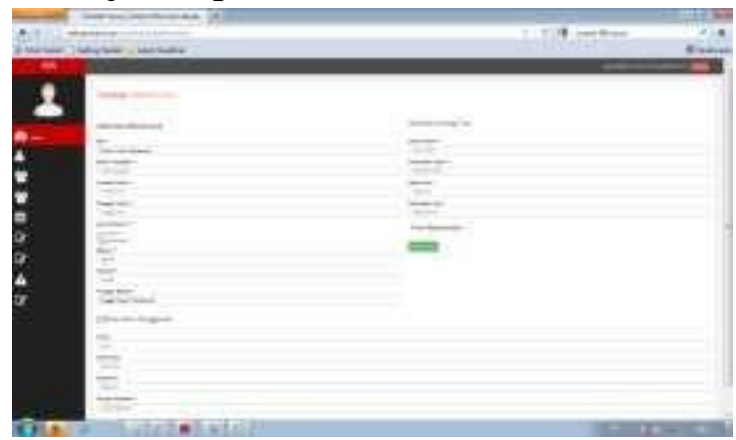

Gambar 5. Halaman Data Mahasiswa

\section{Halaman Data Dosen}

Halaman data dosen adalah suatu data dosen yang mengajar di Aikom, yang berisi kode dosen, nama dosen, no telepon, dan pendidikan terakhir. Admin bisa menambahkan data dosen baru dengan cara mengisikan isian seperti pada gambar kemudian klik tambah data. Yang ditunjukan pada Gambar 6, kemudian klik tambah data untuk menyimpan

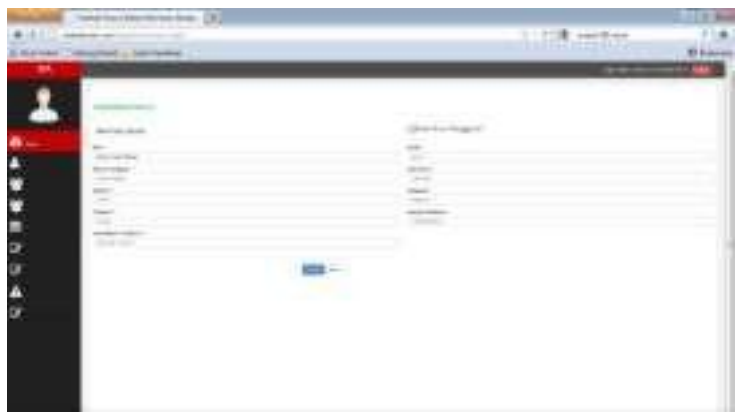

Gambar 6. Halaman Data Dosen

\section{Halaman Data Mata Kuliah}

Dalam sub data berikut merupakan halaman mata kuliah yang digunakan sebagai inputan dalam memasuki mata kuliah yang digunakan di Aikom, yang berisi kode mata kuliah, nama mata kuliah, dan nilai standar minimum.Yang ditunjukan pada Gambar 7

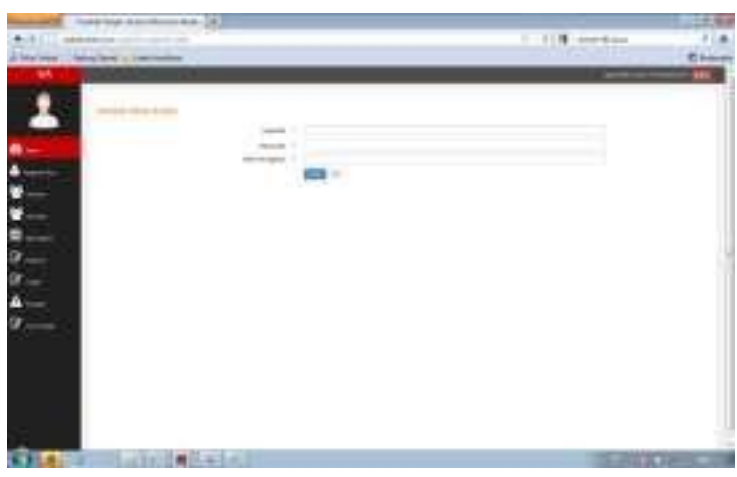

Gambar 7. Halaman Data Mata Kuliah

\section{Halaman Data Nilai}

Merupakan halaman data nilai mahasiswa yang digunakan sebagai inputan dalam memasuki nilai pada Perguruan Tinggi, yang berisi nilai dan nama nilai.Yang ditunjukan pada Gambar 8

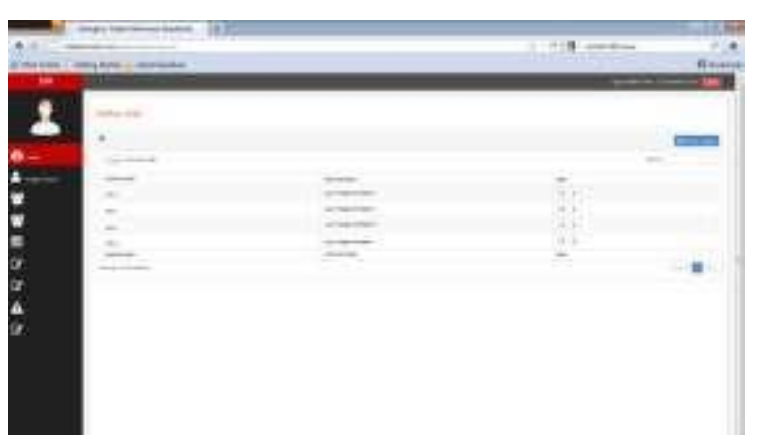

Gambar 9. Halaman Data Nilai 


\section{Usability Testing}

Responden yang digunakan dalam pengujian Usability Testing ini berjumlah 30 orang. Jumlah ini dipilih sesuai dengan penelitian yang pernah dilakukan sebelumnya mengenai jumlah responden, yang mengatakan bahwa responden Usability Testing tidak boleh terlalu banyak. Pengujian sistem merupakan tahap menguji sistem dengan proses penginstalan suatu kasus kedalam sistem sehingga dapat mengatahui kesesuaian sistem dengan rancangan. Selain itu pengujian sistem juga digunakan untuk mengindentifikasi masalah yang mungkin terjadi pada sistem. Pengujian program dilakukan untuk mengetahui apakah program yang telah dibuat dapat berjalan dengan baik atau tidak. Pengujian program dilakukan dengan cara mendemokan program dan memastikan bahwa komponen-komponen dari sistem telah berfungsi sesuai rancangan dan bertujuan untuk menghindari kesalahan program sebelum diterapkan dalam sistem. Berikut ini merupakan beberapa hasil pengujian Sisitem Informasi Akademik

Berdasarkan Hasil Analisis Usability Testing yang diperoleh maka akan diperoleh evaluasi yang di lakukan sistim informasi akademik telah memenuhi kriteria Usability yaitu efektifitas dan efisiensi serta kepuasan pengguna dalam menggunakan aplikasi tersebut. Namun berdasarkan analisis kualitatif yang dilakukan secara manual melalui hasil Task Scenarios dan kuesioner SUS, menurut beberapa responden sistim infomasi akademik ini sangat mudah dan gampang untuk dipahami akan tetapi program tersebut harus dirancang agar lebih menarik banyak peminat karena progaram tersebut masih terlihat biasabiasa saja.

\section{Rekomendasi Perbaikan}

a. Rekomendasi secara umum

Secara umum, rekomedasi yang diberikan terkait dengan penggunaan Beckgrounds pada tampilan aplikasi pada penambahan instrumen serta warna tombol/ item menu, yang direkomendasikan oleh beberapa responden. Menurut respon, untuk tampilan Wallpaper/Backgrounds, ada baiknya mneggunakan gambar yang Beckgrounds-nya memiliki tampilan aplikasi selain itu responden juga merekomendasikan untuk menambahkan Instrumen tersebut dengan tujuan untuk menghilangkan kejenuhan penggunaan

b. Rekomendasi terhadap Game Education Rekomendasi ini disampaikan oleh beberapa responden terkait dengan tampilan mupun konten pada halaman Game Education, respon juga merekomendasikan untuk menambahkan permainan lainya seperti Vollyball dan Golf dan juga menambahakan Instrumen agar User lebih tertarik pada permainan tersebut

\section{KESIMPULAN}

1. Sistem Informasi Akademik sebelumnya ada yang dilakukan secara manual, tetapi ada juga yang sudah menggunakan system informasi, maka dalam penelitian ini ingin menggunakan Perancangan dan Usability Evaluation Prototipe Sistem Informasi Akademik Menggunakan Metode RAD.

2. Dalam Sistem ini digunakan untuk proses pencarian data mahasiswa, data dosen,data, data nilai, materi kuliah dan pembuatan laporan menjadi lebih efektif dan efisien karena penyimpanan data sudah dalam bentuk data base. 


\section{Saran}

Peneliti menyarankan dari hasil rekomendasi melalui Usability dapat dijadikan sebagai bahan masukan guna mengembangkan sistim informasi akademik (SIA) Aikom Ternate, secara berkelanjutan agar menjadi lebih baik dan memilih kualitas yang lebih tinggi, serta perlu adanya pengembangan sistim informasi akademik ini.

\section{DAFTAR PUSTAKA}

[1]. Laudon Laudon, 2012, Managing The Digital Firm, Global Edition, Pearson Education Limited.

[2]. J.Nielsen,"Usability 101: Introduction to

Usability,’2012.[Online].Available: https://www.nngroup.com/articles/us ability-101-introduction-to-usability/. [Accessed:17-Apr2017].

[3]. Weber, Ron. "information system Control and Audit” Prentice Hal Inc., America. 1999.

[4]. C. Laudon and Jane P. Laudon, “ Manajement Information System Managing The Digital Firm 7th Ed. New Jersey, United State: Prentice.

[5]. J.O'Brien, and G.Marakas, "Management Information System," 8thEd McGraw Hill Education, New York, 2008

[6]. Nur Rochmah Dyah P.A, Efawan Retza Arsandy, Sistem Informasi Geografis Temoat Praktek Dokter Spesialis diProvinsi D.I Yogyakarta Berbasis Web, Jurnal Informatika Mulawarman, Vol. 10 No. 1 Edisi Februari 2015, ISSN 1858-4853 (Print), ISSN 2597-4963 (Online)

[7]. Sitna Hajar Hadad, "Rancang bangun system Rekomendasi Obyek Wisata Menggunakan Metode Algoritma Vfi5" Jurnal Ilmiah Teknik Elektro, Volume 04 nomor 2, September 2017, e-ISSN 2527-9572, p-ISSN 2354-8924,

[8]. M. Safi, Pengembangan Aplikasi Sumber Daya Sekolah Berbasis Web
Menggunakan Metode Rapid Application Development (Rad), Jurnal POSITIF, Volume I, No.2, Mei 2016: pp33 - 42. ISSN 24609552

[9]. Gandhi Narrottama, "Perancangan dan Implementasi Sistem Informasi Tugas Akhir Fakultas Teknologi Informasi UKSW Berbasis Web dengan Menggunakan Rapid Application Development (RAD)",

[10]. Unika Kartika Dewi, Yusi Tjroni Mursityo, Rekyan Regasari Mardi Putri, "Analisis Usabelity Aplikasi Mobile Pemesanan Layanan Taksi Perdan Menggunakan Metode Webuse Dan Heuristic Evaluation" yang dipublikasikan Vol. 2, No 8, Agustus 2018 e-ISSN: 2548964X Vol. 2, No 8 Agustus 2018, hlm. 2909-2918 http://Jptiik.ub.ac.id

[11] (John Brooke Redhatch Consulting Ltd). J. Brooke. (1986). SUS: A "Quick and Dirty" Usability Scale [Online]. Available: http://cui.unige.ch/isi/iclewiki/_media/ipm:test- suschapt.pdf

[12]. Sharfina, Z. \& Santoso, H.B. (2016). An Indonesia Adaptation of the System Usability Scale (SUS). ICACSIS

[https://ieeexplore.ieee.org/docment/ 7872776/citatio ns\#citations]

[13]. E Turban, R.K Rainer, and R.E. Potter, Introduction to Information Technology, John Wiley \& Sons, 2005.

[14]. Try Handayani, Yayu Sumiyati Bin Taher, Alfanugrah Hi Usman, Arisandy Ambarita, Aplikasi Pemeriksaan Biaya Instalasi Tegangan Listrik Rendah Berbasis Web pada PT.PPILN Maluku Utara, IJIS-Indonesian Journal On Information system, Volume 4 Nomor 1 April 2019, e-ISSN 25486438, p-ISSN 2614-7173 